\title{
PROFESI GURU \& PROFESIONALISME DALAM DUNIA PENDIDIKAN
}

\author{
Siti Najmi Hafizhah \\ Email: sitinajmi6@gmail.com \\ Program Studi Pendidikan IPS Fakultas Keguruan dan Ilmu Pendidikan \\ Universitas Lambung Mangkurat \\ Banjarmasin
}

\begin{abstract}
Abstrak
Profesi keguruan adalah sebuah bidang pekerjaan yang sudah ditekuni di dalam proses pembelajaran oleh guru-guru yang secara professional bisa mengajar dan menyampaikan materi kepada peserta didik dalam bidang dan keahlian yang dimiliki oleh seorang guru. Peranan profesi keguruan di dalam pendidikan sangatlah penting, karena dengan adanya profesi ini santlah membantu agar terlaksananya pembelajaran yang lebih efektif dan efisien. Profesi guru sangatlah penting untuk generasi bangsa, karena tanpa seorang guru anak bangsa akan banyak yang kurangan pengetahuan dan ilmu yang didapatkan sangatlah sedikit.

Guru dalam proses pendidikan memegang peranan strategi terutama dalam upaya membentuk watak bangsa melalui pengembangan kepribadian dan nilai-nilai yang di inginkan. Guru adalah jabatan profesional yang memilik tugas pokok yang amat menentukan dalam proses pertumbuhan dan perkembangan peserta didik. Untuk tugas pokok tersebut mencakup keseluruhan unsur yang terlibat dan berperan dalam proses pembelajaran. Dengan adanya profesionalisme yang dimiliki seorang guru maka akan membantu pengetahuan dan keterampilan dan wawasan yang lebih luas yang dimiliki oleh peserta didik, sehingga akan membuat memajukan pendidikan yang ada di Indonesia
\end{abstract}

Kata kunci : Profesi guru, profesionalisme, dan kompetensi 


\section{PENDAHULUAN}

Profesi guru merupakan profesi yang dapat menentukan masa depan bangsa ini. Guru tanpa menguasai bahan pelajaran, strategi pembelajaran, mendorong siswa belajar untuk mencapai prestasi yang tinggi maka,segala upaya peningkatan kualitas pendidikan tidak akanmencapai hasil yang maksimal. Kualitas pendidikan sangat ditentukan oleh berbagai faktor, namun yang paling utama dan sangat dominan adalah kualitas professional seorang guru. Suatu pekerjaan atau jabatan yang disebut profesi tidak dapat dipegang oleh sembarang orang, akan tetepi memerlukan suatu persiapan melelui pendidikan dan pelatihan yang dikembangkan khusus untuk itu seseorang yang melakukan pekerjaan namun tidak memiliki keahlian di bidang itu belum bisa dikatakan sebagai profesi, maksudnya profesi sendiri bias dikakatan sebagai pekerjaan atau sebuah jabatan yang sebelumnya sseorang itu sudah memiliki keahlian di bidang tersebut. Artinya keahlian itu didapatkan dengan cara mengenyam pendidikan maupun latihan yang sudah dipelajarai selama mengenyam dunia pendidikan. Profesi juga diartikan sebuah kegiatan yang dilakukan secara penuh waktu, sedangkan pekerjaan dapat dilakukan secara paruh waktu, profesi membutuhkan latar belakang pendidikan dan keahlian yang mumpuni, sehingga mampu bertanggungjawab atas apa yang telah dikerjakannya.

Pengertian guru sebagai profesi maksudnya jabatan yang sangat membutuhkan keahlian secara khusus untuk menjadi seorang guru kecuali sudah ada keahlian yang dimiliki dalam bidang pendidikan. Saat ini banyak di luar sana orang yang jadi guru namun belum seseuai bidang pendidikan dan keahlian yang dimiliki tidak cukup dan itu belum bisa dikatakan sebagai profesi guru. Guru sebagai salah satu profesi yang harus diakui dalam kehidupan masyarakat guru harus diakui sebagai profesi yang sejajar sama tinggi dan duduk sama rendah dengan profesi-profesi lainnya, seperti dokter, hakim, jaksa, akuntan, desainer interior, arsitektur, dan masih banyak yang lainnya. Sebagai profesi, guru memenuhi kelima ciri atau karakteristik yang melekat pada guru. Salah satu ciri guru sebagai profesi yang amat penting adalah guru harus memiliki kemampuan sesuai dengan standar kompetensi yang telah ditetapkan. Guru juga harus selalu mengembangkan dan 
memperluas pengetahuan serta kompetensinya apalagi pada masa globalisasi seperti sekarang.

Profesi guru sangatlah penting untuk generasi bangsa, karena tanpa seorang guru anak bangsa akan banyak yang kurangan pengetahuan dan ilmu yang didapatkan sangatlah sedikit. Seperti yang kita ketahui guru merupakan kesatuan yang tidak dapat di pisahkan , karena dengan adanya guru semua kegiatan pedidikan bisa bejalan lancar. Guru dalam proses pendidikan memegang peranan strategi terutama dalam upaya membentuk watak bangsa melalui pengembangan kepribadian dan nilai-nilai yang di inginkan. Profesi guru adalah orang tua di sekolah. Guru adalah orang yang mampu menjadi inspirator dan motivator bagi anak bangsa. Seorang guru harus memiliki keahlian dalam bidangya dan mampu mentransformasikan ilmunya kepada anak didiknya. Seorang guru tidak hanya dituntut untuk mampu mengajar dengan baik, namun juga mampu mendidik anak didik sehingga menjadi anak yang intelektual dan bermoral tinggi.

\section{PERAN GURU SEBAGAI SEBUAH PROFESI}

Menjadi seorang guru haruslah ada memiliki pengetahuan dan pemahaman untuk menjadi pendididik yang handal agar menjadi seorang guru yang professional, maka dari itu seorang yang sudah melalui mengenyam pendidikan dengan sesuai biadangnya bias dikatan sebagai profesi sehingga bias melalukan pekerjaan dengan sesuai bidang dengan berdasarkan pengalaman yang dimiliki. Seorang guru merupakan suatu profesi, yang artinya suatu jabatan yang sudah diperlukan di dalam keahlian khusus untuk menjadi seorang guru dan juga tidak bias dilakukan oleh sembarang orang yang di luar dari bidang pendidikan tersebut.

Guru adalah jabatan profesional yang memilik tugas pokok yang amat menentukan dalam proses pertumbuhan dan perkembangan peserta didik. Untuk tugas pokok tersebut mencakup keseluruhan unsur yang terlibat dan berperan dalam proses pembelajaran. Seorang guru memerlukan persyaratan profesional yang diperoleh melalui pendidikan yang dirancang khusus untuk itu sehingga dalam melaksanakan tugasnya, guru akan terhindar dari kesalahan, karena bila terjadi kesalahan, hal itu akan berakibat fatal terhadap masa depan peserta didik dan tentu saja amat merugikan dunia pendidikan. Dengan demikian, 
guru memerlukan pendidikan profesional yang dapat menghasilkan guru yang memiliki kemampuan profesional yang disyaratkan oleh jabatan guru sebagai sebuah profesi.

Guru dalam proses pendidikan, memiliki posisi dan peran yang amat sentral dan menentukan, karena itu guru sebagai profesi memer-lukan peryaratan profesional tertentu yang harus dIpenuhi oleh setiap guru. Untuk menjadi guru yang memiliki pengetahuan dan wawasan yang baik maka seorang guru harus mengenyam dunia pendidikan agar bias memberikan ilmu yang didapatkan sesuai dengan bidang dan keahlian. Sehingga dengan adanya profesi maka bisa memberikan pemahaman dan penjelasan yang baik kepada peserta didik.

Dalam peran, hak, dan kewajiban seorang dan dosen guru dalam undang-undang sudah seimbang, dapat dilihat dari perbandingan antara hak dan kewajiban profesi guru. Keseimbangan tersebut antara hak dan kewajiban ini yang membuat guru mampu bekerja secara optimal dan menerima timbal balik yang pantas serta melaksanakan tugas sesuai dengan kode etik dari seorang guru dan dosen, tidak ada guru maupun dosen yang lebih banyak hak dari pada kewajiban yang dilakukan dan begitu pula sebaliknya lebih banyak kewajiban dari pada hak yang diterima, meskipun demikian memang masih banyak saja hal ini terjadi. Tetapi saat ini masih banyak guru yang sudah melaksanakan kewajiban namun belum mendapatkan hak-hak yang semestinya bisa mereka dapatkan. Terutama di daerah yang jauh dari kota, selain sarana dan prasarana yang masih kurang, kesejahteraan kehidupan guru yang bisa dicapai dari penerimaan hak belum mampu dinikmati seluruh guru.

Adapun pengertian peran, hak, dan kewajiban menurut Surya (2005) dalam kunandar (2007), guru yang profesional akan tercermin dalam pelaksanaan pengabdian tugas-tugas yang ditandai dengan keahlian baik dalam materimaupun metode. Selain itu juga ditunjukkan melalui tanggung jawabnya dalam melaksanakan seluruh pengabdiannya. Guru profesional pada intinya adalah guru yang memiliki kompetensi yang di persyaratkan untuk melakukan tugas pendidikan dan pengajaran, yang dimaksud dengan kompetensi dalam UU No. 14 Tahun 2005 adalah seperangkat pengetahuan,keterampilan,dan perilakuyang harus dimiliki, dihayati, dan dikuasai oleh guru atau dosen dalam 
melaksanakan tugas ke profesionalan. Kompetensi tersebut termasuk : kompetensi pedagogik, kepribadian, sosial, professional.

\section{GURU INDONESIA DAN TANTANGAN PROFESIONALISME}

Dengan adanya profesionalisme yang dimiliki seorang guru maka akan membantu pengetahuan dan keterampilan dan wawasan yang lebih luas yang dimiliki oleh peserta didik, sehingga akan membuat memajukan pendidikan yang ada di Indonesia. Melalui profesionalisme seorang guru maka akan mutlak diperlukan dalam proses kegiatan belajar mengajar, karena guru menjadi urat nadi dalam keberhasilan proses tersebut.

Seorang guru memiliki tanggung jawab dalam keilmuan, guru bekerja bukan atas tekanan kebutuhan belajar untuk peserta didiknya, namun itu adalah atas tuntutan professional, dan ini adalah batas kebebasan yang dimaksud. Peserta didik dan profesionalisme seorang guru juga bebas menyelidiki dan mengekspresi kebenaran tanpa tuntutan orang lain. Jadi kebebasan akademik adalah konsep yang mulia dan mendasar memberikan kebebasan akademik kepada peserta didik tanpa memberikan tuntutan dan peserta didik bisa memutuskan pilihan yang bisa dilakukan dan kajian yang mereka kaitkan selama melalukan selama proses belajar mengajar.

Kompetensi yang harus dimiliki seorang guru agar menjadi guru yang professional diantaranya: kompetensi pribadi, kompetensi sosial dan kompetensi professional. Keberhasilan seorang guru dalam proses mengajar di dalam menjalankan profesinya sangat ditentukan oleh ketiganya dengan penekanan pada kemampuan mengajar. Kompetensi profesional seorang guru adalah seperangkat kemampuan yang harus dimiliki oleh seorang guru agar ia dapat melaksanakan tugas mengajarnya dengan berhasil dan peserta didik bisa mendaptkan wawasan baru serta pengetahuan dan keterampilan yang dimilikinya bisa dikembangkan dalam kehudupan yang mana itu akan berguna di masa yang akan dating jika diasah secara terus-menerus. Maka dari itu, dengan adanya guru yang profesional dan berkualitas maka akan mampu mencetak anak bangsa yang berkualitas bagi pendidikan yang ada di Indonesia. 


\section{SIMPULAN}

Profesi guru merupakan profesi yang dapat menentukan masa depan bangsa ini. Guru tanpa menguasai bahan pelajaran, strategi pembelajaran, mendorong siswa belajar untuk mencapai prestasi yang tinggi maka,segala upaya peningkatan kualitas pendidikan tidak akanmencapai hasil yang maksimal. Seorang guru dalam proses pendidikan memegang peranan strategi terutama dalam upaya membentuk watak bangsa melalui pengembangan kepribadian dan nilai-nilai yang di inginkan. Guru adalah jabatan profesional yang memilik tugas pokok yang amat menentukan dalam proses pertumbuhan dan perkembangan peserta didik.

Guru adalah jabatan profesional yang memilik tugas pokok yang amat menentukan dalam proses pertumbuhan dan perkembangan peserta didik. Untuk tugas pokok tersebut mencakup keseluruhan unsur yang terlibat dan berperan dalam proses pembelajaran. Seorang guru memerlukan persyaratan profesional yang diperoleh melalui pendidikan yang dirancang khusus untuk itu sehingga dalam melaksanakan tugasnya, guru akan terhindar dari kesalahan, karena bila terjadi kesalahan, hal itu akan berakibat fatal terhadap masa depan peserta didik dan tentu saja amat merugikan dunia pendidikan.

Kompetensi yang harus dimiliki seorang guru agar menjadi guru yang professional diantaranya: kompetensi pribadi, kompetensi sosial dan kompetensi professional. Keberhasilan seorang guru dalam proses mengajar di dalam menjalankan profesinya sangat ditentukan oleh ketiganya dengan penekanan pada kemampuan mengajar. 


\section{REFERENSI}

Aqib, Zaenal (2010), Profesionalisme Guru Dalam Pembelajaran. Surabaya,Insan Cendikia

Efendi, I., Prawitasari, M., \& Susanto, H. (2021). Implementasi Penilaian Pembelajaran Pada Kurikulum 2013 Mata Pelajaran Sejarah. Prabayaksa: Journal of History Education, 1(1), 21-25.

Janawi, (2012), Kompetensi Guru: Citra Guru professional. Alfabeta, Bandung.

Prof. Dr. H.M. Fakry Gaffar, M.Ed., Rektor UPI Periode 199\&- 2000 -2004, dan 2005.

Susanto, H. (2020). Profesi Keguruan. Banjarmasin: FKIP Universitas Lambung Mangkurat.

Susanto, H., \& Akmal, H. (2018). Efektivitas Penggunaan Aplikasi Pembelajaran Berbasis Mobile Smartphone Sebagai Media Pengenalan Sejarah Lokal Masa Revolusi Fisik Di Kalimantan Selatan Pada Siswa Sekolah Menengah Atas. HISTORIA: Jurnal Program Studi Pendidikan Sejarah, 6(2), 197-206.

Susanto, H., Irmawati, I., Akmal, H., \& Abbas, E. W. (2021). Media Film Dokumenter Masuknya Islam Ke Nusantara dan Pengaruhnya Terhadap Keterampilan Berpikir Kritis Siswa. HISTORIA: Jurnal Program Studi Pendidikan Sejarah, 9(1).

Syaharuddin, S., \& Susanto, H. (2019). Sejarah Pendidikan Indonesia (Era Pra Kolonialisme Nusantara sampai Reformasi). Banjarmasin: FKIP Universitas Lambung Mangkurat. 